\title{
Analysis of the spatial and seasonal variation in catchability of red grouper, Epinephelus morio (Valenciennes, 1828), in the Campeche Bank before overfishing (1973-1977)
}

\author{
Análisis de la variación espacio-temporal en capturabilidad del mero, Epinephelus morio \\ (Valenciennes, 1828) en el Banco de Campeche antes de su sobrepesca (1973-1977)
Jorge A. López-Rocha1, Mirtha O. Albañez-Lucero², Francisco Arreguín-Sánchez² and Juan A. de Anda-Montañez \\ ${ }^{l}$ Unidad Multidisciplinaria de Docencia e Investigación, Facultad de Ciencias, Universidad Nacional \\ Autónoma de México,Sisal, Yucatán, C.P. 97130, México \\ ${ }^{2}$ Centro Interdisciplinario de Ciencias Marinas-IPN, Av. Instituto Politécnico Nacional $s / n$, \\ Col. Playa Palo de Santa Rita, La Paz, B.C.S. 23096, México \\ ${ }^{3}$ Centro de Investigaciones Biológicas del Noroeste, Mar Bermejo $N^{\circ} 195$, Col. \\ Playa Palo de Santa Rita Apdo. Postal 128, La Paz, B.C.S. 23090, México
}

jlopezr@ipn.mx

\begin{abstract}
Resumen.- La pesquería de mero Epinephelus morio en el Banco de Campeche, frente a la costa norte de la Península de Yucatán, está sobreexplotada. Las principales causas son la elevada presión de pesca en zonas de agregación reproductiva y en zonas de crianza de juveniles. Se realizó un análisis de la variación espacio-temporal de la capturabilidad, usando datos de 1973 a 1977, con el objetivo de detectar las zonas de mayor vulnerabilidad del mero según su estado de desarrollo (juveniles, preadultos y adultos). Los resultados mostraron que durante la época de reproducción (enero-marzo) la capturabilidad de los adultos fue mayor en la parte oriental del Banco de Campeche. Se encontraron centros de alta capturabilidad en juveniles durante todas las estaciones del año en las regiones cercanas a Celestún, Dzilam de Bravo, Río Lagartos y el Cuyo. Se recomienda la creación de zonas de restricción de pesca en dichas áreas con el objetivo de reducir la mortalidad por pesca para permitir la recuperación de la población
\end{abstract}

Palabras clave: Agregación reproductiva, zonas de restricción de pesca, vulnerabilidad

\section{Introduction}

The red grouper, Epinephelus morio (Valenciennes, 1828), is a demersal species exploited by three fishery fleets: 1) a fleet of Mexican small vessels in coastal areas, 2) a Mexican mid-sized vessels fleet, and 3) a Cuban large vessels fleet. The fishing, which is carried out year round, generates a considerable number of jobs and contributes to the regional economy (Arreguín-Sánchez et al. 1997). Currently, almost $100 \%$ of red grouper landings are exported to the United States: hence, the fishery is an important source of foreign revenue (BurgosRosas \& Pérez-Pérez 2006).

\begin{abstract}
The red grouper Epinephelus morio fishery in the Campeche Bank, northern coast of the Yucatan Peninsula, is overfished. The main causes are high fishing pressure in areas of reproductive aggregation and juvenile nursery zones. An analysis of the spatial-seasonal variation in catchability was undertaken using data from 1973 to 1977, with the aim to detect areas of higher vulnerability to fishing, taking into account the red grouper developmental stages (juvenile, pre-adults, and adults). Results showed that the adult catchability was higher during the reproductive period (January-March) in the eastern part of the Campeche Bank. High catchability zones for juveniles were found along the year in coastal areas near Celestún, Dzilam de Bravo, Río Lagartos, and El Cuyo. We recommend these locations to be considered as fishing restricted areas to reduce fishing mortality and promote stock recovery.
\end{abstract}

Key words: Spawning aggregations, fishing restricted areas, vulnerability

The coastal fleet uses short lines and long lines of 150 fishhooks, the mid-sized fleet uses 7 to 10 rowboats (locally named 'alijos'), operating a long line of $\sim 150$ fishhooks each. Since 1990, long lines attached to hydraulic reels containing 1,500 to 2,000 fishhooks were implemented. The Cuban fleet uses large fishing vessels with six small boats (named 'cherneras') operating long lines containing 350 fishhooks. Since 1972, annual landings have progressively declined. In 1972, landings reaching 20,000 t were taken but recent (2000s) annual catches averaged about 6,000 t (Burgos-Rosas \& PérezPérez 2006). 
The red grouper of the Campeche Bank is overfished (Giménez-Hurtado et al. 2005, Burgos-Rosas \& PérezPérez 2006). In 2003, its estimated biomass was $~ 45,500$ $\mathrm{t}$ well below the Reference Limit Point of $\sim 74,500 \mathrm{t}$ (Burgos-Rosas \& Pérez-Pérez 2006), and about one third of the stock size in the early 1970s.

In spite of its strong territorial behavior, the red grouper regularly moves along the northern shelf off the Yucatan Peninsula (around 90,000 $\mathrm{km}^{2}$ ) with larger densities at the eastern side during winter (Valdés \& Padrón 1980, Arreguín-Sánchez et al. 1997, ArreguínSánchez \& Pitcher 1999, Hernández \& Seijo 2003), mostly associated to the spawning aggregations, being this behavior a key element for the managing of the fishery. The reproductive aggregation makes red grouper highly vulnerable in specific areas and seasons (ArreguínSánchez \& Pitcher 1999).

The fishery is regulated by the government by issuing fishing permits and a minimum legal size of $30 \mathrm{~cm}$ total length. Since 2003, a closed season was implemented, from $15^{\text {th }}$ February to $15^{\text {th }}$ March, to protect red grouper during reproductive season. Recently, accomplishing closed season, a new minimum legal size was defined as $51 \mathrm{~cm}$ fork length. The Cuban fleet is governed by an agreement that sets a catch quota that is revised annually amounting 3,500 $\mathrm{t}$ of demersal fish from which red grouper constitutes around 70\% (Burgos-Rosas \& PérezPérez 2006).

Alternative management policies have been proposed to promote population recovery. Giménez-Hurtado (2005) recommends closure for waters $<20 \mathrm{~m}$ deep to protect juveniles and greater than $70 \mathrm{~m}$ deep to protect adults. Other suggestions accounts for critical areas (for nursery and spawning aggregation) and the need of their protection (Giménez-Hurtado 2005, Burgos-Rosas \& Pérez-Pérez 2006).

Arreguín-Sánchez \& Pitcher (1999) and López-Rocha \& Arreguín-Sánchez (2008) demonstrated that catchability of the red grouper in the Campeche Bank is affected by their aggregation reproductive behavior when fish density increases. Estimates of spatial and seasonal variation of catchability could be useful in developing management actions, since catchability reflects areas and seasons when red grouper is more vulnerable to fishing and is related to high yields. This study is focused on determining spatial and seasonal variation of catchability and its implication for fishery management by considering Fishing Restricted Areas.

Although the data used in this paper come from the years when the red grouper was not overfished (1973-
1977), a strong relationship between bottom type and the red grouper distribution has documented (AlbañezLucero \& Arreguín-Sánchez, 2009). Considering that there was no disturbance that results in changes in the bottom distribution, it is reasonable expects at least a similar pattern in terms of spatial distribution of red grouper despite the current depleted state of the stock. In this sense, the results of this study may serve as a guide to the location Restricted Fishing Areas, recommending reassess these areas with current information.

\section{Material and methods}

This study used information from 668 fishing trips (taken from the period 1973-1977) by the mid-sized fleet working the Campeche Bank which covered about $80 \%$ of the fishing grounds and overlap other fleets in a range of $60 \%$ to $85 \%$. This information is part of the red grouper database maintained by the Centro Regional de Investigación Pesquera (Regional Center of Fishing Research) of the National Institute of Fishing, in Yucalpeten, Yucatan, Mexico. The information included the number of effective days of fishing (EDF), an estimate of the geographical fishing position, catch size, and the frequency of each length category associated with each fishing trip.

Estimates of catchability vary with the zone, stage of development (juvenile, pre-adult, and adult) and season. In order to analyze the spatial data, the Campeche Bank was divided in cells $\left(1 / 2^{\circ} \times 1 / 2^{\circ}\right)$ and estimates of catchability were computed for each cell. For each stage of development, catchability-at-length was estimated for length intervals of $2 \mathrm{~cm}$ (within the range 20 to $90 \mathrm{~cm}$ TL). The categories established were: juveniles (20-30 $\mathrm{cm}$ TL), pre-adults $(30-50 \mathrm{~cm} \mathrm{TL})$, and adults $(>50 \mathrm{~cm}$ TL). Average catchability for each stage was weighed by catch per unit effort (U). Seasonal changes in catchability were also obtained.

Catchability-at-length were estimated following Arreguín-Sánchez (1996) and Arreguín-Sánchez \& Pitcher (1999), who used the Leslie's transition matrix (Shepherd 1987, Caswell 1988) and length frequency distributions. The model represents the structure of the population, as follows:

$$
\mathrm{N}(\ell, \mathrm{t}+1)=\mathrm{A}(\ell, \mathrm{k}) \mathrm{N}(\ell, \mathrm{t}),
$$

where $\mathrm{N}(\mathbf{I}, \mathrm{t})$ is the population size at time $\mathrm{t}, \mathrm{k}$ and $\mathbf{I}$ are successive intervals of length, and $\mathrm{A}$ is the transition matrix that depends on growth and mortality. The length distribution frequencies of each fishing trip, in terms of catch per unit effort (number of individuals $\bullet \mathrm{EDF}^{-1}$ ), were 
grouped by month and by cell $\left(1 / 2^{\circ} \times 1 / 2^{\circ}\right)$. The resulting vectors of relative abundance by size class $[N(I, t)]$ were used to estimate catchability through the transition matrix in each cell and on a monthly basis within the five- year analysis.

Growth and mortality were expressed as the product of two values (Shepherd 1987):

$$
\mathrm{A}(\ell, \mathrm{k})=\mathrm{G}(\ell, \mathrm{k}) \times \mathrm{S}(\mathrm{k}),
$$

where $\mathrm{G}$ is the effect of growth in the absence of mortality and $\mathrm{S}$ is survival and effect of fishing gear selection.

Estimating the matrix $\mathrm{G}(\mathbf{I}, \mathrm{k})$ (assuming that growth of red grouper can be represented by the von Bertalanffy growth equation) was done by assigning probabilities of growth to each size class, according to Shepherd (1987) (Table 1). The survival matrix $\mathrm{S}(\mathrm{k})$ was expressed in terms of mortality:

$$
S(k)=\exp [-Z(k) t]=\exp -[M+q(k, t) s(k) E(t)],
$$

where $\mathrm{S}(\mathrm{k})$ are elements of the main diagonal of the survival matrix (Caswell 1988), Z(k)t is total instantaneous mortality rate for the $\mathrm{k}^{\text {th }}$-length group at time $\mathrm{t}, \mathrm{M}$ is the instantaneous rate of natural mortality, $\mathrm{s}(\mathrm{k})$ is the probability of fishing gear selection for the $\mathrm{k}^{\text {th }}$-length group, $\mathrm{E}(\mathrm{t})$ is the fishing effort to time $t$, and $q(k, t)$ is the catchability for the $k^{\text {th }}$ length group to time $\mathrm{t}$.

Equation 3 was solved for $\mathrm{q}(\mathrm{k}, \mathrm{t})$ by numerical iteration using the minimum squared algorithm in the fitting process. Estimations were made using the Catchability program (Martínez-Aguilar et al. 1999), including the following values as inputs: asymptotic length $\left(\mathrm{L}_{\infty}\right)$ was $87 \mathrm{~cm}$, growth coefficient $(\mathrm{K})$ was 0.12 year $^{-1}$, and natural mortality $(\mathrm{M})$ was 0.3 year $^{-1}$ (ArreguínSánchez \& Pitcher 1999). The factor of selection for each length class $\mathrm{s}(\boldsymbol{I})$ was set as $\mathrm{s}(\boldsymbol{I})=1$ because information was no available.
Analysis of catchability-at-length, as proposed by Arreguín-Sánchez \& Pitcher (1999), needs additional assumptions for spatial analysis. Here, we assumed that probability of distribution of red grouper within areas is related to the type of substrate following Albañez-Lucero \& Arreguín-Sánchez (2009) whose abundance is reflected by the catch per unit effort (U), representing population size $(\mathrm{N})$ through the relationship $(\mathrm{U}=\mathrm{N} / \mathrm{q})$, where catchability $q$ varied with density of fish (ArreguínSánchez \& Pitcher 1999). Therefore, variations in catchability can be assigned to changes of catchability among areas. Spatial variation of catchability was estimated as:

$$
\operatorname{Ln}[\mathrm{U}(\ell, \mathrm{z}) / \mathrm{U}(\ell, \bullet)]=\operatorname{Ln}[\mathrm{q}(\ell, \mathrm{z}) / \mathrm{q}(\ell, \bullet)]
$$

where $\mathrm{U}(\boldsymbol{I}, \mathrm{z})$ is the catch per unit of effort of length $\boldsymbol{I}$ in zone $\mathrm{z}, \mathrm{U}(\boldsymbol{I}, \bullet)$ is the average of catch per unit of effort of length $\boldsymbol{I}$ in the entire study area, $\mathrm{q}(\boldsymbol{I}, \mathrm{z})$ is the catchability of length $\boldsymbol{I}$ in zone $\mathrm{z}$, and $\mathrm{q}(\boldsymbol{I}, \bullet)$ is the average catchability of length $\boldsymbol{I}$ in the entire study area. This could be interpreted as the deviation of catchability-at-length in zone $\mathrm{z}$ relative to the average catchability-at-length pattern. Arreguín-Sánchez \& Pitcher (1999) demonstrated this ratio is a linear function of size, and can be represented as:

$$
\begin{gathered}
\operatorname{Ln}[\mathrm{U}(\ell, \mathrm{z}) / \mathrm{U}(\ell, \bullet)]=\ell(\mathrm{z})+\ell(\mathrm{z}) \ell \\
\text { where } \ell(\mathrm{z})=\operatorname{Ln}[\mathrm{q}(\ell+1, \mathrm{z}) / \mathrm{q}(\ell, \bullet)]-\operatorname{Ln}[\mathrm{q}(\ell+1, \bullet) / \mathrm{q}(\ell, \bullet)]
\end{gathered}
$$

The intercept $/(\mathrm{z})$ is interpreted as the relative vulnerability of smallest fish and can also be interpreted as an index of recruitment to the area. The slope $I(\mathrm{z})$ expresses the rate of change of catchability-at-length relative to the mean pattern.

Table 1

Criteria for assigning probabilities in the growth matrix (G) per length class according to Shepherd (1987)

Criterios para la asignación de probabilidades de la matriz de crecimiento (G) por clase de longitud según Shepherd (1987)

\begin{tabular}{lll}
\hline 1. $\mathrm{G}(\ell, \mathrm{k})=0$ & ...if... & $\mathrm{L}(\mathrm{k}+1)<\tilde{\mathrm{L}}(\ell)$ \\
2. $\mathrm{G}(\ell, \mathrm{k})=[(\mathrm{L}(\mathrm{k}+1)-\tilde{\mathrm{L}}(\ell))] / \Delta \mathrm{L}$ & $\ldots$. if... & $\mathrm{L}(\mathrm{k})<\tilde{\mathrm{L}}(\ell)<\mathrm{L}(\mathrm{k}+1)$ \\
3. $\mathrm{G}(\ell, \mathrm{k})=1.0$ & $\ldots$.if... & $\tilde{\mathrm{L}}(\ell)<\mathrm{L}(\mathrm{k})$ and $\mathrm{L}(\mathrm{k}+1)<\tilde{\mathrm{L}}(\ell+1)$ \\
4. $\mathrm{G}(\ell, \mathrm{k})=[(\tilde{\mathrm{L}}(\ell+1)-\mathrm{L}(\mathrm{k}))] / \Delta \mathrm{L}$ & $\ldots . .$. & $\mathrm{L}(\mathrm{k})<\tilde{\mathrm{L}}(\ell+1)<\mathrm{L}(\mathrm{k}+1)$ \\
5. $\mathrm{G}(\ell, \mathrm{k})=0$ & $\ldots$. if... & $\tilde{\mathrm{L}}(\ell+1)<\mathrm{L}(\mathrm{k})$ \\
6. $\mathrm{G}(\ell, \mathrm{k})=1.0$ (for the last length interval) & $\ldots . . .$. & $\mathrm{L}=\mathrm{Lmax}$ and $\tilde{\mathrm{L}}(\ell)<\mathrm{L}(\mathrm{k})$ \\
\hline
\end{tabular}

$\ell$ and $k$ are successive length intervals; $\Delta \mathrm{L}=\mathrm{L}(\mathrm{k}+1)-\mathrm{L}(\mathrm{k})$ is the interval size (constant for all lengths); $\tilde{\mathrm{L}}(\ell)=[\mathrm{L}(\ell)-\lambda] / \rho$; $\lambda=\mathrm{L}_{\infty} \cdot(1-\rho)$; and $\rho=\exp (-\mathrm{K} \cdot \Delta \mathrm{t}) ; \mathrm{K}$ and $\mathrm{L}_{\infty}$ are parameters of von Bertalanffy growth model 


\section{Results}

Catchability estimates ranked as follows: preadults $\left(\mathrm{q}_{\mathrm{pre}}\right.$ $=0.06940)$, adults $\left(\mathrm{q}_{\mathrm{adu}}=0.04949\right)$, and juveniles $\left(\mathrm{q}_{\mathrm{juv}}=\right.$ 0.03245 ). Based on seasonal variations, the maximum catchability of adults occurred in winter and progressively diminished during summer and autumn. Higher catchabilities of pre-adults occurred in winter and progressively diminished during spring and summer, before switching upward again in autumn. Catchability of juveniles occurred in winter and spring progressively diminished in the summer and autumn (Fig. 1).

Maximum values of catchability of adults were registered during the spring and the winter of 1973. Catchability of preadults is more variable with peaks in winter and spring. Catchability of juveniles shows the maximum values in spring, except in 1973 when higher catchability occurred in winter (Fig. 2).

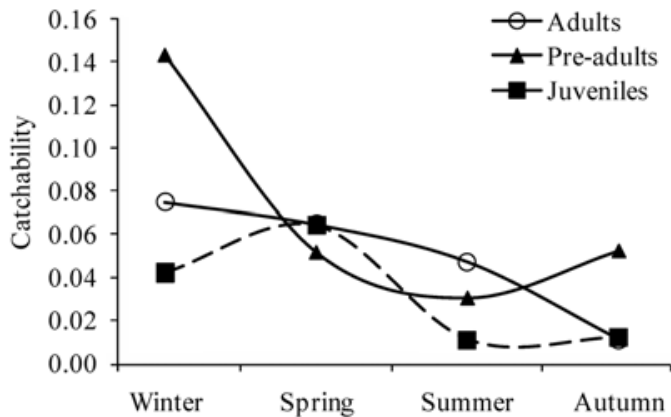

Figure 1

Average seasonal pattern of catchability for the red grouper $E$. morio on the Campeche Bank, Mexico, per stage of development from 1973 to 1977

Variación estacional de la capturabilidad por sector de población de mero E. morio en el Banco de

Campeche, México de 1973 a 1977

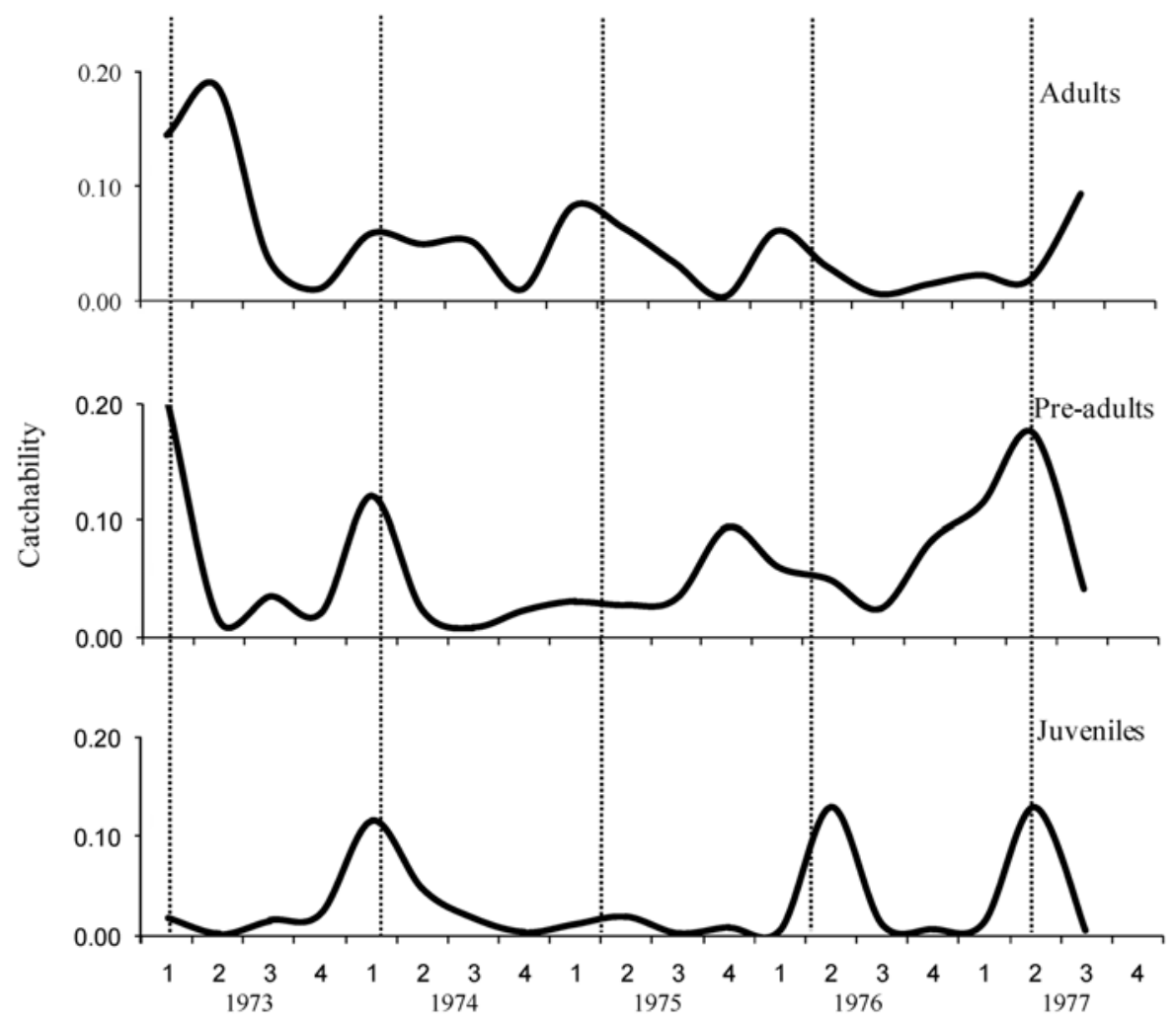

Figure 2

Catchability trends of red grouper $E$. morio (1973-1977) by stage of development on the Campeche Bank, Mexico, ( 1 = winter, $2=$ spring, $3=$ summer, $4=$ autumn $)$

Tendencias de la capturabilidad por sector de población de mero E. morio (1973-1977) en el Banco de Campeche, México, $(1=$ invierno, $2=$ primavera, $3=$ verano, $4=$ otoño $)$ 


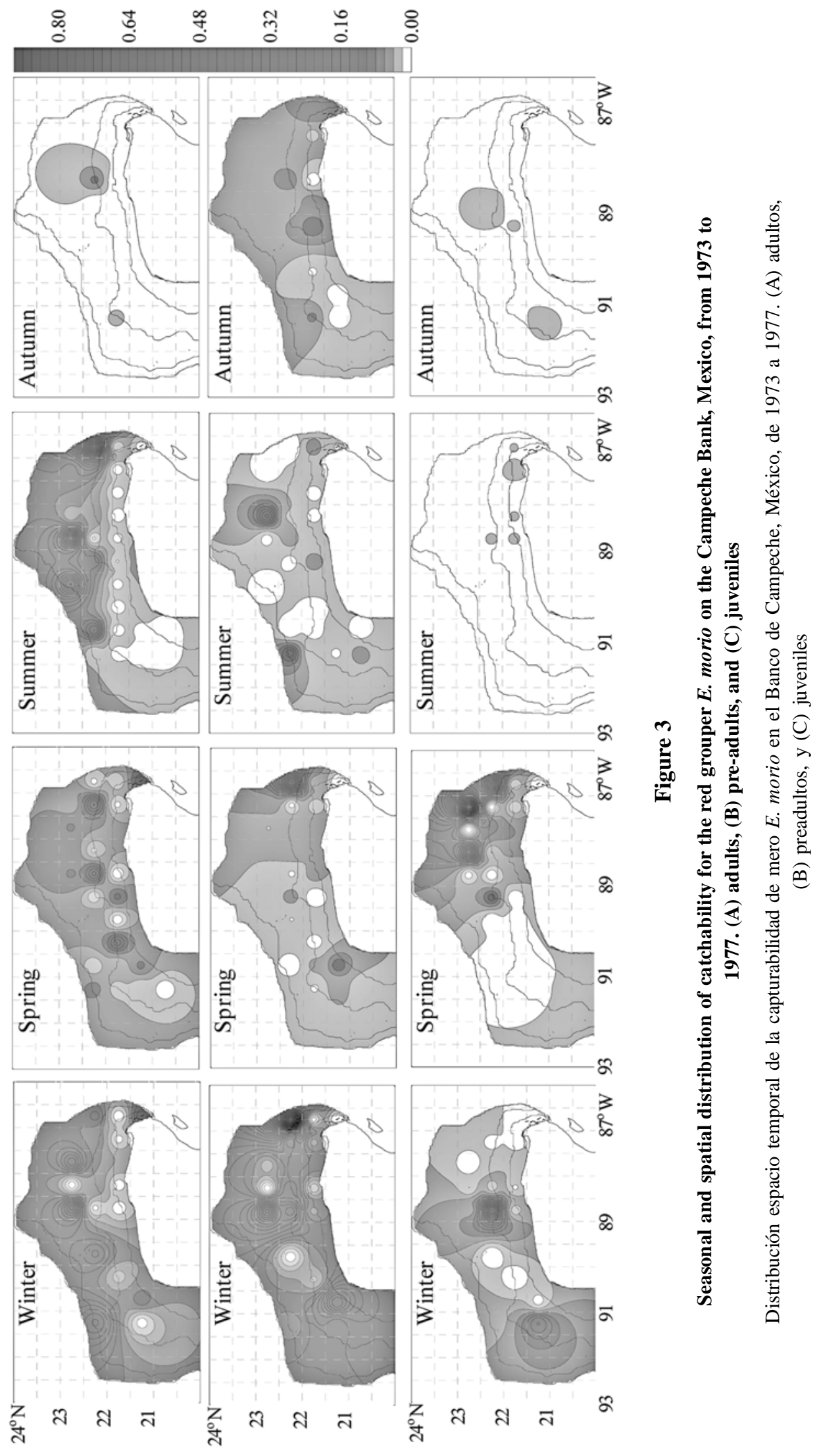


The zones of higher catchability values for adults during winter were in the northeastern part of the Campeche Bank $\left(22.5^{\circ}-23.0^{\circ} \mathrm{N}, 87.5^{\circ}-89.0^{\circ} \mathrm{W}\right)$ and in the west $\left(22.0^{\circ}-22.5^{\circ} \mathrm{N}, 90.5^{\circ}-92.0^{\circ} \mathrm{W}\right)$. Distribution in spring was similar to winter. High catchability values were found during summer on the northeastern region $\left(22.0^{\circ}\right.$ $\left.22.5^{\circ} \mathrm{N}, 86.5^{\circ}-87.0^{\circ} \mathrm{W}\right)$ and on the north, near Arrecife Alacranes $\left(\sim 22.6^{\circ} \mathrm{N}, 89.7^{\circ} \mathrm{W}\right)$. In autumn, higher catchabilities were found to the eastern continental shelf $\left(\sim 22.5^{\circ} \mathrm{N}, 88.0^{\circ} \mathrm{W}\right)$; and on the west, similar to conditions in the winter (Fig. 3A).

Higher catchability values pre-adults were observed during the winter and spring in the east $\left(22.0^{\circ}-22.5^{\circ} \mathrm{N}\right.$, $\left.86.5^{\circ}-87.0^{\circ} \mathrm{W}\right)$ and in the southwest near Celestún-Sisal $\left(21.0^{\circ}-22.0^{\circ} \mathrm{N}, 90.0^{\circ}-91.0^{\circ} \mathrm{W}\right)$. In summer areas with higher values of catchability were far from the coast; in autumn, higher catchabilities were near to the coast (Fig. 3B).

High catchabilities of juveniles in winter occurred in the central $\left(22.0^{\circ}-22.5^{\circ} \mathrm{N}, 88.5^{\circ}-89.5^{\circ} \mathrm{W}\right)$ and west $\left(21.0^{\circ}-22.0^{\circ} \mathrm{N}, 91.0^{\circ}-92.0^{\circ} \mathrm{W}\right)$ regions of the north continental shelf of Yucatan Peninsula. In spring, higher catchabilities occurred in the northeast border-end of the continental shelf; and in summer and autumn higher catchabilities were near the coast (Fig. 3C).

Computations based on Equation 5 show the departure
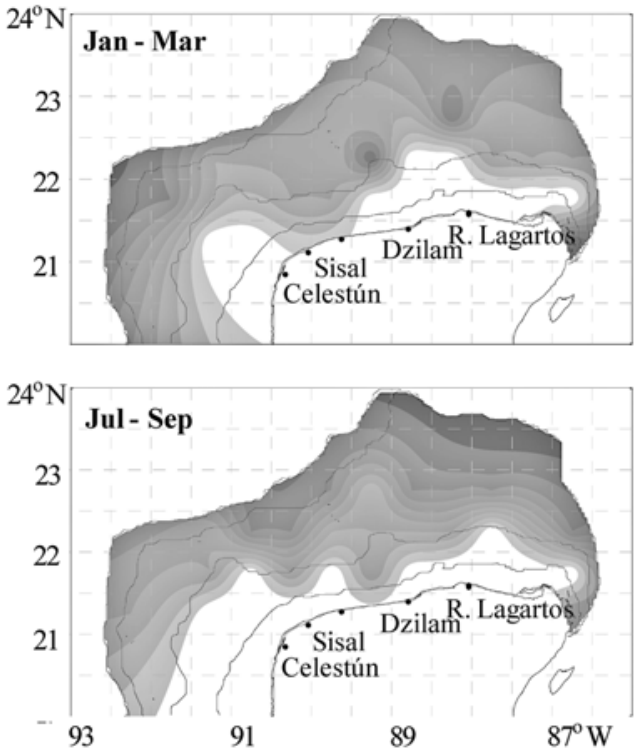

of catchability-at-length for each zone with regard to the average pattern, where Figs. 4 and 5 represent positive and negative deviations respectively. Positive values for the $\beta$ coefficient indicate higher vulnerability in the larger sizes and negative numbers indicate higher vulnerability in the smaller sizes. A pattern of positive deviations occurred in area farther from the coast. Evident change occurs in autumn toward high vulnerability of smaller fishes (Table 2). In winter, positive values of $\beta$ were constant north of $22^{\circ} \mathrm{N}$, except in the central part of the Campeche Bank. In this season, negative values of $\beta$ appear along the coast, especially at Dzilam de Bravo

\section{Table 2}

Seasonal variation of the $\beta$ and $\alpha$ coefficients (Equation 5) for the red grouper $\boldsymbol{E}$. morio fishery on the Campeche Bank, Mexico, from 1973 to 1977

Variación estacional de los coeficientes $\beta$ y $\alpha$ (ecuación 5), en la pesquería de mero E. morio en el Banco de Campeche, México, de 1973 a 1977

\begin{tabular}{lcc}
\hline & $\beta$ & $\alpha$ \\
\hline Winter & 0.0405 & 2.42 \\
Spring & 0.0392 & 2.67 \\
Summer & 0.0363 & 2.63 \\
Autumn & -0.0210 & 0.86 \\
\hline
\end{tabular}

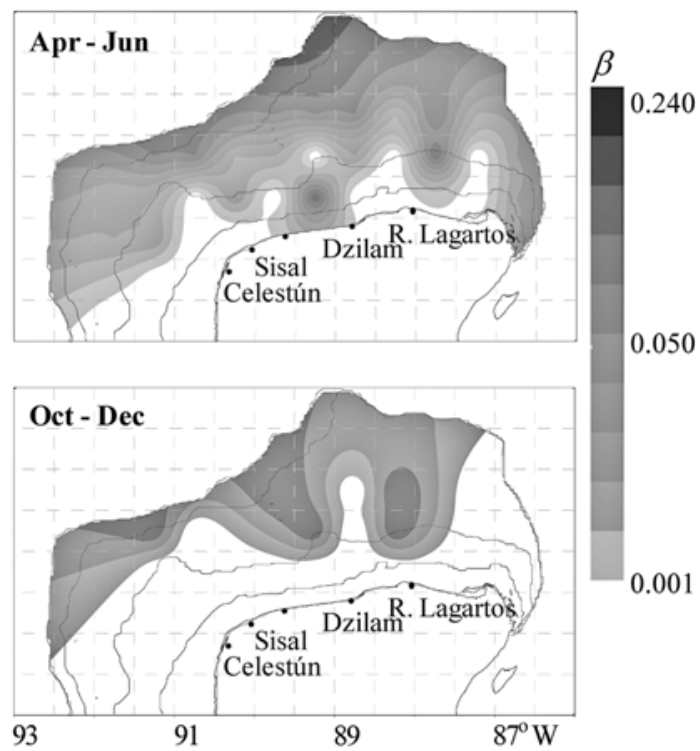

Figure 4

Seasonal distribution of the positive values of the $\beta$ coefficient (Equation 5) (indicating high catchability for adults) for the red grouper E. morio fishery on the Campeche Bank, Mexico, from 1973 to 1977

Distribución temporal de valores positivos del coeficiente $\beta$ (ecuación 5) (indicando alta capturabilidad en adultos) en la pesquería de mero E. morio en el Banco de Campeche, México, de 1973 a 1977 
and Río Lagartos (Fig. 5). During spring, high positive values of $\beta$ appear in the broad north region and moderate values to the east and west (Fig. 4). The western area had negative values of $\beta$, which indicates higher vulnerability of smaller fishes (Fig. 5). In summer, the pattern of positive deviations in the larger sizes in the northern area continued. In addition, there were important areas of negative values for $\beta$ near Río Lagartos, Dzilam de Bravo, and west of Celestún (Fig. 5) meaning higher vulnerabilities for smaller fish. Near Celestún, a pattern of constant catchability-at-length also occurred. During autumn, the pattern was completely different than for other seasons. Negative $\beta$ values were distributed almost across the entire Bank, including the northern area, where this pattern had not appeared (Fig. 5).

\section{Discussion}

Our survey showed spatial and seasonal variations of catchability-at-length pattern among the developmental stages of the red grouper in the Campeche Bank from 1973 to 1977 . Catchability was higher in adults during winter and spring in the central and eastern parts of the Campeche Bank. Arreguín-Sánchez \& Pitcher (1999) reported that catchability changes seasonally in proportion to population density, which in turns suggests that adults aggregate during late winter and earlier spring in the eastern region of the Campeche Bank. Arreguín-
Sánchez et al. (1997) suggested that immature individuals have similar seasonal movements than adults, but in areas nearer the coast. Our findings showed that the scenario from 1973 to 1977 reflects that high catchability for juveniles and preadults were found in coastal areas, but also in areas of medium and greater depths, which suggest transition areas with juveniles moving to the north in autumn.

During spring and summer from 1973 to 1977 , high catchability areas were widely dispersed within the bank, especially on the west during summer. In autumn, there was a notable decline in catchability for all developmental stages. Hernández \& Seijo (2003) suggested that red grouper is not attracted by fishing bait because they are moving to the eastern part of the bank, there is high dispersion of red grouper at this season, or by changes in fleet dynamics because change of target species by fleet to the Mexican four-eyed octopus Octopus maya. This situation is more notable for adults and pre-adults. From 1973 to 1977 , during autumn the departure of catchability-at-length, as represented by the $\beta$ coefficient of Equation 5 (Fig. 5), had predominantly negative values, which represents a higher vulnerability for small fishes. Important areas were near Celestún-Sisal, Dzilam de Bravo-Río Lagartos, and El Cuyo. In these coastal areas, high catchability occurred during all seasons, clearly indicating the importance of coastal areas for juveniles.
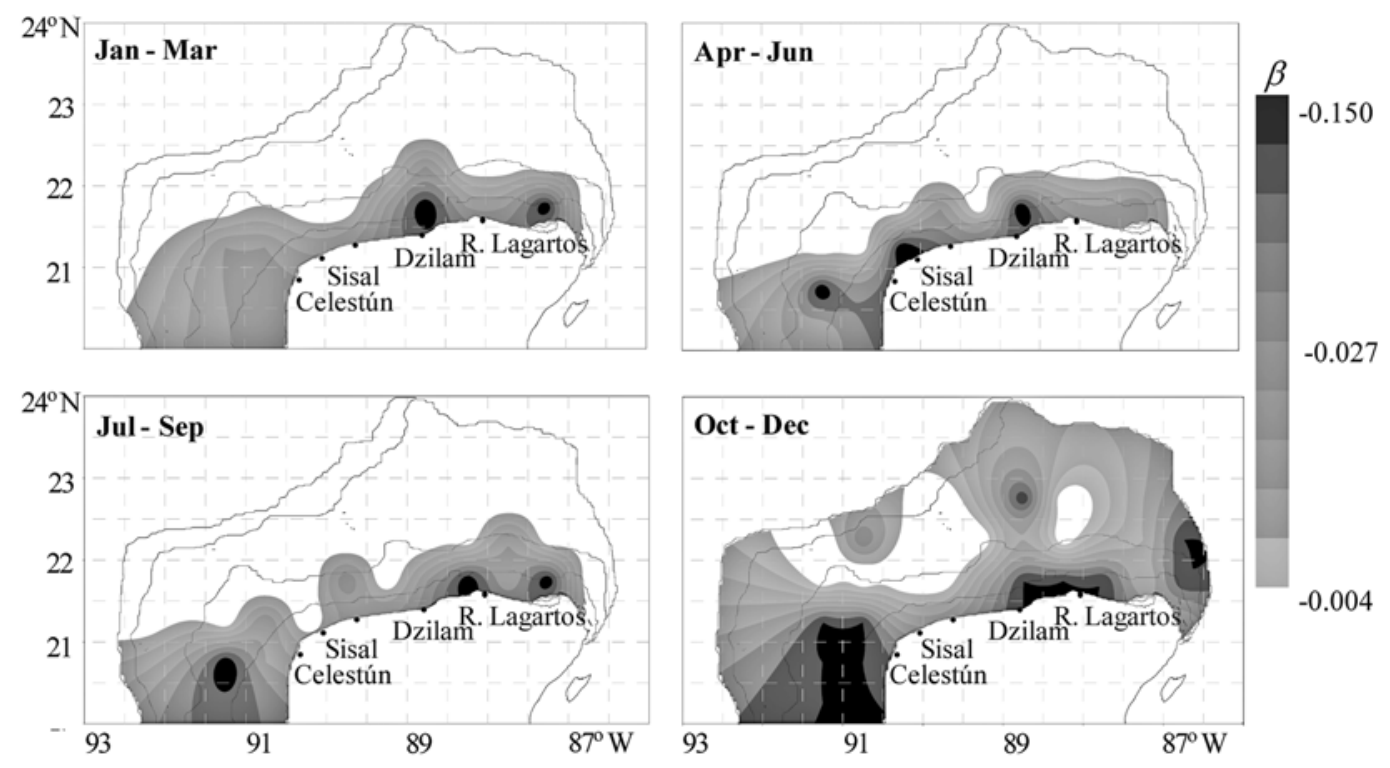

Figure 5

Seasonal distribution of the negative values of the $\beta$ coefficient (Equation 5) (indicating higher catchability for juveniles) for the red grouper E. morio fishery on the Campeche Bank, Mexico, from 1973 to 1977

Distribución temporal de valores negativos del coeficiente $\beta$ (ecuación 5) (indicando alta capturabilidad en juveniles) en la pesquería de mero E. morio en el Banco de Campeche, México, de 1973 a 1977 


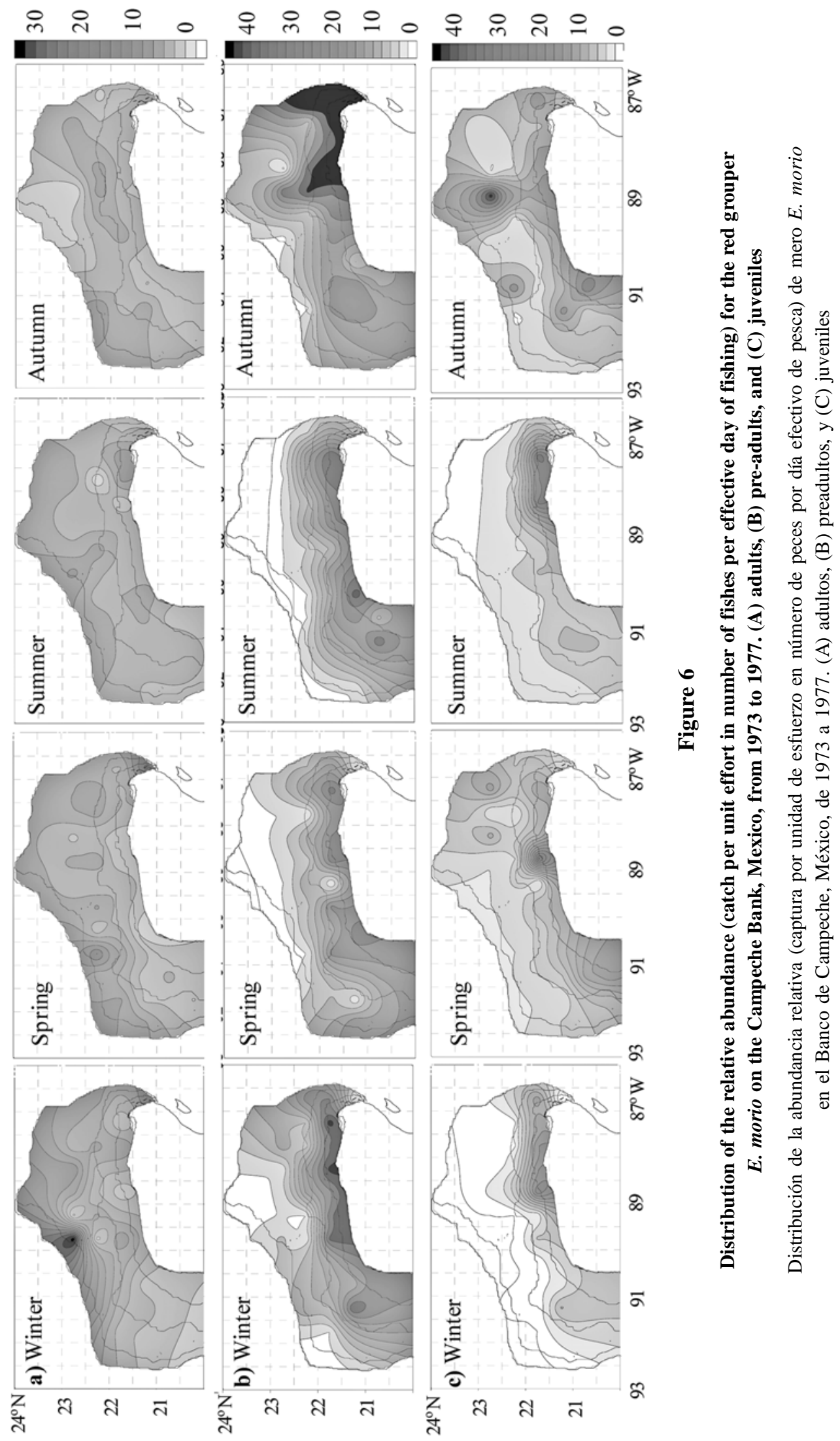


Our estimation of catchability was based on the historical period of greatest landings (1973-1977), when the red grouper stock was not overfished yet as it is considered now; therefore, if catchability is considered as a measure of interaction between the resource and the fishing effort, catchability estimates of a depleted population could be reflecting more the fishing strategies than the population behavior. Thus, is important the current estimates of catchability as well as, the knowledge of the spatial-temporal patterns of catchability when the red grouper was not overfished.

At least two situations have been recognized as responsible for the decline of the red grouper stock: 1) a high fishing pressure in areas where reproductive adults aggregate, and 2) high fishing pressure in nursery areas (Burgos-Rosas \& Pérez-Pérez 2006). Protection of critical habitats has been suggested for the red grouper stock to recover by creating Fishing Restricted Areas in places where juveniles concentrate and where reproduction takes place (Giménez-Hurtado 2005, Burgos-Rosas \& Pérez-Pérez 2006, López-Rocha \& Arreguín-Sánchez 2008). The Mexican government has established temporary fishing bans, from February 15 to March 15 each year since 2003, for the entire Campeche
Bank offering protection during reproductive season. However, this measure has a limited value since the red grouper reproduction begins on January and continues through March (Brulé et al. 1999, Giménez et al. 2003). A variation of this government policy to achieve more effective protection could be a ban on fishing but inside reproduction areas for at least those three months. This implementation may represent a potential solution that combines the stock protection and the short-term interests of fishers. Locations of high density of groupers on the eastern continental shelf varied, but coincided with the high catchability region. Thus, a protection area that covered this region was defined within the ranges $22^{\circ}$ $23.5^{\circ} \mathrm{N}$ and $86^{\circ}-89^{\circ} \mathrm{W}$. Despite the evidence that reproduction can occur elsewhere than just in the eastern area (Brulé et al. 1999, Giménez et al. 2003) and that some authors (Shapiro 1987, Sadovy 1996) suggested red grouper does not form typical spawning aggregations than other serranid species, red grouper density in the eastern Campeche Bank during reproductive season is over five times than that showed during other seasons; this fact coincides with criteria suggested by Domeier \& Colin (1997). Such red grouper aggregation corresponded to higher catchability values; therefore, fishing bans in

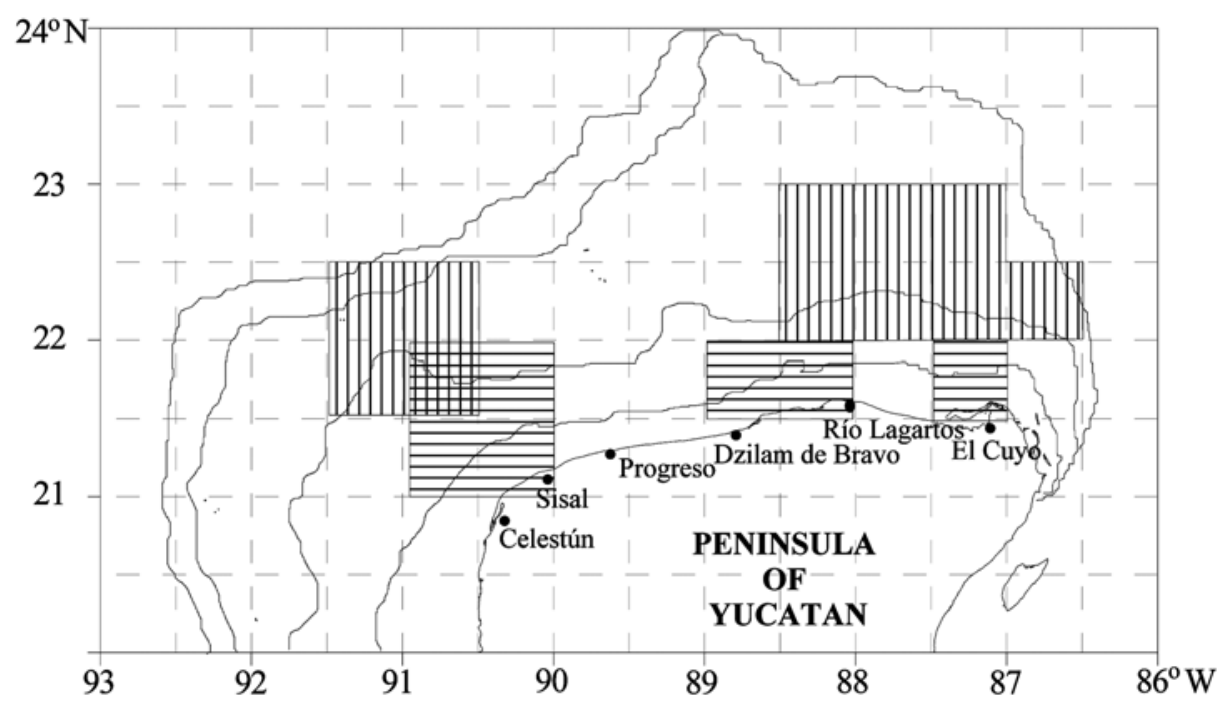

Figure 7

Proposed zones from this study as Fishing Restricted Areas for the red grouper E. morio fishery on the Campeche Bank, Mexico. Areas with vertical lines are suggested to protect adults while areas with horizontal lines are suggested to protect juveniles

Áreas propuestas de este estudio como zonas de restricción de pesca en la pesquería de mero E. morio en el Banco de Campeche, México. Zonas con líneas verticales indican zonas de protección de adultos mientras que las áreas con líneas horizontales indican zonas de protección de juveniles 
these regions, implemented as Fishing Restricted Areas, may give desirable results for proper management. Within this framework, Fig. 6 shows seasonal changes of the stock abundance (1973-1977) (Albañez-Lucero \& Arreguín-Sánchez 2009) related bottom types. It is clearly noticed that highest concentrations of fishes coincide with highest values of catchability.

Juvenile had four areas with high catchability adjacent to Celestún, Dzilam de Bravo, Río Lagartos, and El Cuyo locations, the same areas reported by Renán et al. (2003) as nursery areas for E. morio and other species of groupers (see Fig. 6). Fishing restrictions in these areas can be considered appropriated since average size-at-firstcapture $(30 \mathrm{~cm} \mathrm{LT})$ is below first maturity size $(50 \mathrm{~cm}$ LT) (Burgos-Rosas \& Pérez-Pérez 2006).

Based on distributions of catchability obtained for 1973 to 1977 and stock abundance (Albañez-Lucero \& Arreguín-Sánchez 2009), Fig. 7 shows areas that may be suitable for Fishing Restricted Areas, which could positively impact red grouper survival by reducing fishing mortality within high densities areas. Certainly is advisable reevaluate the proposed areas with current information. However, as mentioned earlier, due to the strong relationship between the red grouper distribution and the bottom type, one can expect a similar pattern of red grouper distribution at present. Hernandez \& Seijo (2003) analyzed the red grouper distribution in the Campeche Bank from 1984 to 2001. They found significant high abundances every year during January and February in the eastern part of the bank. These results confirm that there has been continuity in the general pattern of red grouper distribution even under overfishing conditions. Therefore, the results obtained in this work can guide the location of Fishing Restricted Areas to promote stock recovery.

\section{Acknowledgments}

We express our gratitude to the European Community for support through the project INCOFISH (contract INCO 003739); SAGARPA-CONACYT (project 12004) and Instituto Politécnico Nacional (projects: 20060579, 20070767, 20080765). JALR was a recipient of a CONACYT doctoral fellowship and FAS is an EDI and COFAA fellow of the Instituto Politécnico Nacional. JAAM thanks Consejo Nacional de Ciencia y Tecnología for financial support (CONACYT operating Grant 290537-IPN). Authors also thank Instituto Nacional de la Pesca for facilitating information on the red grouper fishery. We appreciate the valuable comments of two anonymous reviewers.

\section{Literature cited}

Albañez-Lucero MO \& F Arreguín-Sánchez. 2009 Modelling spatial distribution of red grouper (Epinephelus morio) of Campeche Bank, México, with respect substrate. Ecological Modelling 220(20): 2744-2750.

Arreguín-Sánchez F. 1996. Catchability, a key parameter for fish stock assessment. Reviews in Fish Biology and Fisheries 6: 221-242.

Arreguín-Sánchez F \& TJ Pitcher. 1999. Catchability estimates accounting for several sources of variation: application to the red grouper fishery of the Campeche Bank, México. Fishery Bulletin 97: 746-757.

Arreguín-Sánchez F, M Contreras, V Moreno, R Valdés \& R Burgos. 1997. La pesquería de mero (Epinephelus morio) de la Sonda de Campeche, México. In: Flores-Hernández D, P Sánchez-Gil, JC Seijo \& F Arreguín-Sánchez (eds). Análisis y diagnóstico de los recursos pesqueros críticos del Golfo de México, pp. 307-332. Universidad Autónoma de Campeche. EPOMEX Serie Científica, México.

Brulé T, C Déniel, T Colás-Marrufo \& M Sánchez-Crespo. 1999. Red Grouper reproduction in the southern Gulf of Mexico. Transactions of the American Fisheries Society 128: 385-402.

Burgos-Rosas R \& L Pérez-Pérez. 2006. Mero. In: ArreguínSánchez F, L. Meléndez-Moreno, I Méndez-GómezHumarán, R Solana-Sansores \& C Rangel-Dávalos (eds). Sustentabilidad y pesca responsable en México: evaluación y manejo, pp. 503-522. Instituto Nacional de la Pesca, Secretaria de Agricultura, Ganadería, Desarrollo Rural, Pesca y Alimentación, México.

Caswell H. 1988. Approaching size and age in matrix population models. In: Ebenman E \& L Persson (eds). Sizestructured populations, pp. 85-105. Springer-Verlag, Berlin.

Domeier ML \& PL Colin. 1997. Tropical reef fish spawning aggregations: Defined and reviewed. Bulletin of Marine Science 60: 698-726.

Giménez E, V Moreno, R Burgos \& S Alfonso. 2003. Reproducción y fecundidad de la cherna americana (Epinephelus morio) en el banco de Campeche, México. Oceánides 18: 13-22.

Giménez-Hurtado E. 2005. Análisis de la pesca del mero Epinephelus morio (Serranidae: Pisces, Valenciennes 1928) en el Banco de Campeche. Tesis de Doctorado, Centro de Investigaciones Biológicas del Noroeste, La Paz, 93 pp.

Giménez-Hurtado E, R Coyula-Pérez-Puelles, S Lluch-Cota, AA González-Yáñez, V Moreno-García \& R BurgosRosas. 2005. Historical biomass, fishing mortality, and recruitment trends of the Campeche Bank red grouper (Epinephelus morio). Fisheries Research 71: 267-277.

Hernández A \& JC Seijo. 2003. Spatial distribution analysis of red grouper (Epinephelus morio) fishery in Yucatán, Mexico. Fisheries Research 63: 135-141. 
López-Rocha JA \& F Arreguín-Sánchez. 2008. Spatial distribution of red grouper Epinephelus morio (Serranidae) catchability on the Campeche Bank of Mexico. Journal of Applied Ichthyology 24: 282-289.

Martínez-Aguilar S, E Morales-Bojórquez, F ArreguínSánchez \& JA de Anda-Montañez. 1999. Catchability: programa computarizado para estimar el coeficiente de capturabilidad en función de la longitud, 16 pp. Centro Regional de Investigación Pesquera de La Paz del INP, Centro Interdisciplinario de Ciencias Marinas-IPN, Centro de Investigaciones Biológicas del Noroeste, La Paz.

Renán X, K Cervera-Cervera \& T Brulé. 2003. Probable nursery areas for juvenile groupers along the northern coast of the Yucatan peninsula, Mexico. Proceedings of the Gulf and Caribbean Fisheries Institute 54: 496-505.
Sadovy Y. 1996. Reproduction of reef fish species. In: Polunin NVC \& CM Roberts (eds). Reef fisheries, pp. 15-59. Chapman and Hall, London.

Shapiro D. 1987. Reproduction in groupers. In: Polovina JJ \& S Ralston (eds). Tropical snappers and groupers: biology and fisheries management, pp. 295-325. Westview Press, Boulder.

Shepherd JG. 1987. A weakly parametric method for estimating growth parameters from length composition data. In: Pauly D \& GP Morgan (eds). Length based methods in fisheries research. ICLARM Conferences Proceedings 13: 113-119.

Valdés E \& G Padrón. 1980. Pesquerías de palangre. Revista Cubana de Investigaciones Pesqueras 5: 38-52.

Recibido el 6 de febrero de 2009 y aceptado el 29 de septiembre de 2009 